\title{
Effect of commercialization way on the physicochemical and microbial characteristics of pork
}

\author{
${ }^{1 *}$ Lima, R.N., ${ }^{2}$ Barreto, H.F.M., ${ }^{1}$ Assis, A.P.P., ${ }^{1}$ Figueiredo, J.P.V., ${ }^{1}$ Miranda, M.V.F.G., \\ ${ }^{1}$ Abrantes, M.R., ${ }^{1}$ Silva, J.B.A. and ${ }^{1}$ Lima, P.O. \\ ${ }^{1}$ Department of Animal Sciences, Universidade Federal Rural do Semi-Árido (UFERSA), 59625-900, \\ Mossoró, Rio Grande do Norte, Brazil \\ ${ }^{2}$ Instituto Federal de Educação, Ciência e Tecnologia do Rio Grande do Norte (IFRN), 59700-000, Apodi, \\ Rio Grande do Norte, Brazil
}

\begin{abstract}
Article history:
Received: 23 June 2017

Received in revised form: 14 July 2017

Accepted: 15 July 2017

Available Online: 16 July 2017
\end{abstract}

Keywords:

Meat in natura,

Freezing,

Longissimus dorsi,

Hygienic handling

DOI:

http://doi.org/10.26656/ fr.2017.6.100

\begin{abstract}
The analyze of meat exposed to commercialization, it becomes necessary to know its physicochemical, organoleptic and nutritional characteristics, as well as the conditions of hygiene and preservation. The purpose of this study was to evaluate how different forms of processing and commercialization affect the physicochemical and microbiological parameters of pork loin (Longissimus dorsi). To achieve this, twenty samples of pork loin (Longissimus dorsi) were obtained. Ten samples were fresh and commercialized and handled on a counter and the other ten samples were vacuum-packed and frozen, without manipulation on the counter. The samples were analyzed for enterobacteria, mesophilic bacteria, chemical composition (protein, moisture, ash, fat) and physical parameters $(\mathrm{pH}$, water holding capacity, shear force, cooking loss, color characteristics by the CIE system $\left.L^{*} a^{*} b^{*}\right)$. The data were submitted to analysis of variance and t-test (5\% significance). The physical and microbiological parameters were influenced by the commercial forms evaluated $(\mathrm{P}<0.05)$, except $\mathrm{pH}$ and water holding capacity. Ash, moisture and fat contents did not differ $(\mathrm{P}>0.05)$, while protein content was lower in meat in natura $(\mathrm{P}<0.05)$. Despite the lower level of contamination, frozen meat undergoes significant physical changes that may compromise its quality and consumer acceptance.
\end{abstract}

\section{Introduction}

Pork is consumed in every continent of the world, having great economic importance in several countries. Although the pork industry has become highly competitive and this type of meat is the most consumed in the world, its consumption in Brazil is still lower than beef and chicken (Laurenti et al., 2009). According to Schlindwein and Kassouf (2006), this fact is mainly due to the formation of a negative image associated with pork that is rooted in Brazilian society and is related to possible deleterious effects on consumer health.

Taking into account that improper storage and handling of products of animal origin are factors responsible for the reduction of shelf life and, consequently, deterioration of these products (Oliveira et al., 2008), the form of commercialization has a strong impact on the sensory and microbiological quality of the meat. In cities in the inner region of the country, the commercialization of meat in natura, in street markets, for example, is still common and traditional. But, this is a matter of concern and frequent caution due to the hygienic-sanitary deficiencies, as well as the lack of control with regard to the origin of the commercialized foods (Garcia-Cruz et al., 2000). It should also be considered that food of animal origin and its derived products, when they are not stored or packaged properly, are exposed under unhealthy conditions, subject to the direct action of pathogenic or non-pathogenic microorganisms from environmental contamination and environmental pollution, as well as insects (Germano and Germano, 2008).

However, several methods can be used for proper food preservation, among others, freezing is an important preservation method for meats and derived products. It is based on the fact that low temperatures destroy some microorganisms and prevent the growth of others, thus 
allowing the production of a high-quality product even after a long period of storage (Fontes and Lopes, 1994). However, although microbial deterioration is effectively controlled, deterioration of quality, especially texture, taste and color, still occurs during freezing due to osmotic water removal, myosin denaturation, mechanical damage caused by the formation of ice in the interior of cells, as well as cross-linking and aggregation of myofibrillar ( Monteiro Filho et al., 2002; Xia et al., 2009).

Therefore, the structural characteristics of foods are of great importance for texture properties, which directly affect the sensory perception of food products. Consequently, a basic understanding of how raw material quality and processing parameters influence the structural characteristics of foods is vital to optimize the quality of the final product (Straadt et al., 2007). As regards its quality, pork must have sensory, nutritional, hygienic and health aspects unchanged. Otherwise, the product will be compromised, resulting in economic losses for the industry and the consumer.

Knowing that several factors are important for changes in structural characteristics that may influence consumer perception, Lundgren et al. (2009) suggest that in order to analyze the meat exposed to commercialization, it becomes necessary to know its physicochemical, organoleptic and nutritional characteristics, as well as the conditions of hygiene, preservation, exposure, and commercialization. Thus, the objective of this study was to evaluate how different forms of processing and commercialization affect the physicochemical and microbiological parameters of pork loin (Longissimus dorsi).

\section{Materials and methods}

Twenty samples of pork loin (Longissimus dorsi) were obtained from different points of sales, ten of the samples were in natura, commercialized and manipulated on a counter and the other ten were vacuum -packed and frozen, without manipulation on a counter. During the collection of the samples, records and observations of the hygienic-sanitary conditions of storage and handling of the products were carried out, in accordance with the Resolution RDC no. 216, September 15, 2004 (Brasil, 2004).

In order to evaluate the microbiological quality of the meat, it was followed the methodology described in the official analytical methods for enterobacteria and mesophilic bacteria analyzes, established by the
Normative Instruction no. 62 (Brasil, 2003). The centesimal composition (moisture, protein, and ash) and fat content were evaluated using the methodology described by AOAC (2005) and Folch et al. (1957) respectively.

The $\mathrm{pH}$ of the samples was determined using a HANNA ${ }^{\circledR}$ digital $\mathrm{pH}$ meter $\mathrm{HI}$ 99163, coupled to a penetration electrode, the $\mathrm{pH}$ being measured directly in the muscle (AOAC, 2005). The color was measured in the Konica Minolta colorimeter, CM-700d / 600d (CIE System $\left.\mathrm{L}^{*} \mathrm{a} * \mathrm{~b}^{*}\right)$, whose system considers the coordinates $\mathrm{L}^{*}$ lightness (black/white), a* redness (green/red) and $\mathrm{b}^{*}$ yellowness (blue/yellow). The determination of water holding capacity (WHC) was based on the measurement of water loss released when a pressure was applied to muscle tissue. Based on the difference of the weights (initial - final), it was determined the water holding capacity, expressed in percentage of lost weight of the initial sample (Hamm, 1960).

For the analysis of cooking loss (PPC), the meat samples were weighed and wrapped in aluminum foil. They were then transferred to a grill where they remained until the internal temperature of the muscle reached 71 to $75^{\circ} \mathrm{C}$. Subsequently, the samples were removed from the grill and weighed again for the calculation of the percentage of water loss during the thermal process (Osório et al., 1998). In order to evaluate the shear force, it was used the same samples used in the PPC determination, from which $1 \mathrm{~cm}$ diameter samples were drawn through a nozzle and measured in a texturometer (Texture Analyzer TA-XT-125) coupled to the Warner-Bratzler device, which expresses the force in $\mathrm{kgf} / \mathrm{cm}^{2}$.

The data were submitted to analysis of variance. The effect of the treatments on each variable was compared by means of the t-test, at $5 \%$ probability level. Statistical procedures were conducted using SAS PROC GLM (Statistical Analysis System, version 9.2.).

\section{Results and discussion}

The hygienic conditions of the working environment and the fulfillment of official and legal requirements are important factors in the production and commercialization of safe and quality food (Lundgren et al., 2009). Thus, when assessing the microbiological quality of a food, it is necessary to observe such conditions in order to confront with the results obtained in the laboratory. The counters where the meat in natura 
was being commercialized were in compliance, showing no apparent dirt and being considered regular. However, it was noticeable the presence of dirt in the corridors of the establishments, which could compromise the hygiene of the meat exposed for commercialization.

As for the handlers, in all the counters inspected they used only a cloth to clean the hands and utensils $(100 \%$ of the obvested), not being observed the presence of exclusive washbasins for the hands, which is fundamental for the proper process hand-hygiene. It was also not observed the use of hats and clothing suitable for work $(80 \%)$, similar to that verified by Lundgren et al. (2009). It was also verified that the same people who manipulated the meat were the ones who received the payment $(90 \%)$, thus facilitating the contamination of the meat, which goes against the RDC Resolution no. 216 (Brasil, 2004): food handlers should be clean, wearing caps, smocks and gloves, and should not manipulate money, wear accessories nor eat while performing activities. According to Silva Júnior (1995), personal hygiene is one of the most important requirements related to food hygiene, since man is directly or indirectly responsible for the contamination of food during handling.

Regarding the places of commercialization of frozen meat, there was no direct manipulation since they are vacuum-packed (100\%) and thus commercialized in an adequate manner, with an average temperature of $5^{\circ} \mathrm{C}$. The commercialization of meat in natura is not in accordance with the ordinance n. 304/96, which stipulates that slaughtering establishments for cattle, buffaloes, pigs, and poultry may only deliver meats for commercialization with temperature up to $7^{\circ} \mathrm{C}$ and the meats can only be distributed in standardized cuts, properly packed and identified. All the meat samples evaluated in the street market and in the public market can be considered out of the established standards (Brasil, 1996).

Abrahão et al. (2005) state that, even when obtained from healthy animals, meat is a potential vehicle for biological, physical and chemical contaminants in the several stages of processing, from production, processing, storage, transport and commercialization conditions, with the aggravating fact that throughout the process, the meat is handled by people who, due to lack of guidance or negligence, contribute to the poor quality of the product that reaches the consumer. The lack of slaughterhouses and cold-storage houses specialized in the slaughtering of pigs in the correct way in the region, propitiate the clandestine slaughter of animals and the sale of products of animal origin without sanitary inspection. Even though the commercialization of meat in natura is considered a tradition it may compromise public health by exposure to unfavorable conditions of handling and hygiene.

Microbiological analysis (Table 1) showed that there was more contamination in the samples commercialized in natura $(\mathrm{P}<0.05)$. This result confirms that the handling of the meat under inadequate hygienic-sanitary conditions, confirmed by the visual observation of the commercial places, compromised the sanitary quality, since these deteriorating microorganisms are related to unfavorable hygienic conditions, agreeing with the statement made by Cardoso et al. (2005) that in fresh food of animal origin the occurrence of high numbers of Enterobacteriaceae and aerobic mesophilic bacteria may indicate handling without hygiene care and/or inadequate storage. The investigation of enterobacteria in beef is important because they are associated with outbreaks of foodborne diseases, highlighting Salmonella spp. as the etiological agent (Germano and Germano, 2008).

Table 1. Microbiological analysis of frozen and refrigerated pork

\begin{tabular}{lcccc}
\hline & $\begin{array}{c}\text { In } \\
\text { natura }\end{array}$ & Frozen & $\mathrm{P}$ & $\mathrm{CV}$ \\
\hline $\begin{array}{l}\text { Mesophilic } \\
\text { bacteria } \\
(\log \mathrm{UFC} / \mathrm{g})\end{array}$ & 7.06 & 4.40 & $*$ & 5.72 \\
$\begin{array}{l}\text { Enterobacteriaceae } \\
(\log \mathrm{UFC} / \mathrm{g})\end{array}$ & 5.47 & 3.18 & $*$ & 7.12 \\
\hline * - Significant at $5 \%$; ns - Not significant; CV - Coefficient of \\
$\begin{array}{l}\text { variation. } \\
\text { a }\end{array}$
\end{tabular}

The Brazilian legislation does not establish a standard for total counting of mesophilic aerobic bacteria in raw meat. However, Delazari (1979) observed that meats with bacterial concentrations around $107 \mathrm{CFU} / \mathrm{g}$ (7.0 log CFU/g) are already with their quality compromised in relation to the aroma and the superficial viscosity. This is because the bacteria start using amino acids as a substrate for their growth, which causes the appearance of odors and undesirable aspects (Silva et al., 2002).

The chemical composition (Table 2) was not influenced by commercialization and processing $(\mathrm{P}>$ 0.05 ), except for protein content that was higher in frozen loin $(\mathrm{P}<0.05)$. Fernandes et al. (2016) did not find differences when evaluating the influence of the commercialization form on the chemical composition of the meat.

The $\mathrm{pH}$ did not differ $(\mathrm{P}=0.682)$ taking into account 
the form of commercialization and storage (Table 3) and it showed similar averages to those found by Barbosa et al. (2006) and like the ones attributed by Fox et al. (1980) and Caldara et al. (2012) for pork in PSE condition $(<5.8)$. The $\mathrm{pH}$ value of the meat influences protein denaturation, myofibrils distention and muscle cell shrinkage. This parameter is strongly influenced by pre and posts death biochemical events (Hughes et al., 2014) and in the case of pork, it may be linked to a metabolic dysfunction known as porcine stress syndrome (PSS) that seems to be caused by the presence of the halothane (Hal) gene. When the animals are exposed to stress factors they have a much faster release of sarcoplasmic calcium after bleeding (Ramos and Gomide, 2009). Thus, the results obtained in this study seem to be more related to factors of slaughter or intrinsic to the species than the form of post-maturation storage.

Table 2. Chemical composition of frozen and refrigerated pork

\begin{tabular}{lcccc}
\hline $\begin{array}{l}\text { Chemical } \\
\text { analysis }\end{array}$ & $\begin{array}{c}\text { In } \\
\text { natura }\end{array}$ & Frozen & $\mathrm{P}$ & $\mathrm{CV}(\%)$ \\
\hline Protein & 24.44 & 26.08 & $*$ & 5.19 \\
Moisture & 64.33 & 66.90 & ns & 7.12 \\
fat & 5.58 & 5.31 & ns & 23.21 \\
Ashes & 4.91 & 4.22 & ns & 25.69 \\
\hline
\end{tabular}

* - Significant at 5\%; ns - Not significant; CV - Coefficient of variation.

Table 3. Physical parameters of frozen and refrigerated pork

\begin{tabular}{lcccc}
\hline & $\begin{array}{c}\text { In } \\
\text { natura }\end{array}$ & Frozen & $\mathrm{P}$ & $\mathrm{CV}$ \\
\hline $\mathrm{pH}$ & 5.69 & 5.64 & $\mathrm{~ns}$ & 3.93 \\
Lightness & 56.93 & 52.28 & $*$ & 6.84 \\
Redness (a*) & 1.17 & 0.60 & $*$ & 56.06 \\
Yellowness & 7.15 & 5.19 & $*$ & 19.03 \\
$\mathrm{WHC}^{\mathrm{a}}(\%)$ & 38.90 & 40.77 & $\mathrm{~ns}$ & 18.65 \\
$\mathrm{PPC}^{\mathrm{b}}(\%)$ & 23.63 & 28.88 & $*$ & 18.21 \\
$\mathrm{SF}^{\mathrm{c}}\left(\mathrm{kgf} / \mathrm{cm}^{2}\right)$ & 2.52 & 3.40 & $*$ & 23.37 \\
\hline
\end{tabular}

${ }^{a}$ WHC - Water holding capacity; PPC - Cooking loss; SF Shear force; * - Significant at 5\%; ns - Not significant; CV Coefficient of variation.

In this study, the color-related parameters were influenced by the freezing of pork loin $(\mathrm{P}<0.05)$, with reduction of lightness $\left(\mathrm{L}^{*}\right)$, redness $\left(\mathrm{a}^{*}\right)$ and yellowness (b*) of the meats. According to Xia et al. (2009), the color plays an important role in the appearance, presentation, and acceptability of frozen pork. Kim et al.
(2013), Xia et al. (2009) and Lindahl et al. (2006) noticed an increase of $b^{*}$ and $L^{*}$ in pork subjected to freeze/thaw cycles, associated with greater lipid oxidation of the loin and the formation of metamioglobin, suggesting an acceleration of oxidation and deterioration in myoglobin. However, according to Morgado et al. (2011), the color is also influenced by the packaging material, freezing speed and storage conditions such as temperature, time and light. Thus, loins vacuum-packed, stored under freezing and greater irradiation from the chambers of refrigeration in the supermarkets are darker than those in natura, exposed on counters. Davis et al. (2004) and Zhu et al. (2004) also observed changes in pork color as a function of storage time and the amount of irradiation, making them darker the higher the dose and the storage time, which is consistent with the results obtained in this experiment.

While attributes such as softness, taste, and juiciness are the most important characteristics from the consumer's point of view, their evaluation is difficult before purchase as the product is not visible and can suffer great variation (Verbeke et al., 2010). Hughes et al. (2014) state that there is often a poor correlation between the water holding capacity (WHC) of the raw meat, the water lost during cooking and the juiciness of the final product. As who determines the acceptability of the product is the consumer of the cooked muscle, the changes during cooking are the most important. Thus, although no influence of the commercialization form on the WHC (P>0.05) was observed, the cooking loss was higher in the frozen loin than in the commercialized in natura $(\mathrm{P}<0.05)$. During freezing and thawing of meat, its proteins, mainly myofibrillar proteins, may undergo denaturation resulting in dehydration and it could lose over the time the ability to maintain and retain water (Kołczak et al., 2005). This protein denaturation may be the reason for the greater weight loss during cooking observed in frozen commercialized meats.

The analysis of the softness of the meat, measured by the determination of the shear force, showed a significant difference between the two commercialized forms ( $\mathrm{P}<0.05)$, with a higher value for frozen loin, as mentioned by Xia et al. (2009), who reported that the cutting force of pork increases after a freeze-thaw cycle compared to fresh pork. Freezing is one of the best ways to preserve the original characteristics of a product and avoid organoleptic changes in it. However, the freezing form, specifically in the case of special cuts of meat, can cause loss in product quality, leading to the formation of ice crystals with consequent damage to the integrity of the fibers of the meat, besides causing an increase in the 
loss of water compromising the tenderness of the meat (Liu et al., 2010). Probably, as a result, the consumer is led to purchase meat in natura, often in street markets and public markets, thus encouraging the permanence of this form of commercialization, even with the confirmation of the high rates of nonconformities of these places with the RDC 216.

\section{Conclusion}

The pork loin commercialized in natura shows higher levels of microbiological contamination when compared to the samples under refrigeration and this is mainly associated with the lack of care during manipulation. Despite the lower level of contamination, frozen meat undergoes significant physical changes that may compromise its quality and consumer acceptance.

\section{References}

Abrahão, R.M.C.M., Nogueira, P.A. and Malucelli, M.I.C. (2005). O comércio clandestino de carne e leite no Brasil e o risco da transmissão da tuberculose bovina e de outras doenças ao homem: um problema de saúde pública. Archives of Veterinary Science, 10(2), 1-17.

AOAC. (2005). Official Methods of Analysis. 18th ed. Washington: AOAC.

Barbosa, L., Lopes, P.S., Regazzi, A.J., Guimarães, S.E.F. and Torres, R. A. (2006). Avaliação de características de qualidade da carne de suínos por meio de componentes principais. Revista Brasileira de Zootecnia, 35(4), 417-421.

Brasil. (1996). Ministério da Agricultura Pecuária e Abastecimento. Portaria $\mathrm{n}^{\circ} .304$ de 22 de Abril de 1996, que dispões sobre o comércio de carne embalada que determina os estabelecimentos de abate de bovinos, bubalinos e suínos, somente poderão entregar carnes e miúdos, para comercialização, com temperatura de até 7 (sete) graus centígrados. Diário Oficial [da] República Federativa do Brasil, Brasília, DF, 23 abr. Seção 01, p.6856.

Brasil. (2004). Agência Nacional de Vigilância Sanitária. Resolução RDC no 216 de 15 de Setembro de 2004. Dispõe sobre Regulamento Técnico de Boas Práticas para Serviços de Alimentação. Diário Oficial da União, Poder Executivo, Brasília, DF, 16 set. 2004.

Brasil. (2003). Ministério da Agricultura, Pecuária e Abastecimento. Secretaria de Defesa Agropecuária.
Métodos Analíticos Oficiais para Análises Microbiológicas para Controle de Produtos de Origem Animal e Água. Instrução Normativa nº6, de 26/08/2003. Diário Oficial da União, Brasília, seção I, p.14-51, 18 set.

Caldara, F.R., Santos, V.M.O., Santiago, J.C., Almeida Paz, I.C.L., Garcia, R.G., Vargas Junior, F.M., Santos, L.S. and Nääs, I.A. (2012). Propriedades físicas e sensoriais da carne suína PSE. Revista Brasileira de Saúde e Produção Animal, 13(3), 815824.

Cardoso, A.L.S.P., Castro, A.G.M., Tessari, E.N.C., Baldassi, L. and Pinheiro, E.S. (2005). Pesquisa de Salmonella spp., coliformes totais, coliformes fecais, mesófilos em carcaças e cortes de frango. Revista Higiene Alimentar, 19(128), 144-150.

Davis, K.J., Sebranek, J.G., Huff-Lonergan, E., Ahn, D.U. and Lonergan, S.M. (2004). The effects of irradiation on quality of injected fresh pork loins. Meat Science, 67(3), 395-401.

Delazari, I. (1979). Microbiologia de carnes microrganismos causadores de deterioração da carne e produtos cárneos. Boletim da Sociedade Brasileira de Ciência e Tecnologia de Alimentos, 49(1), 3-39.

Fernandes, R.T.V., Arruda, A.M.V., Costa, M.K.O., Lima, P.O., Santos, L.O.G., Melo, A.S. and Marinho, J.B.M. (2016). Physicochemical and microbiological parameters of frozen and chilled chicken meat. Revista Brasileira de Zootecnia, 45 (7), 417-421.

Folch, J., Lees, M. and Stanley, G.H.S. (1957). A simple method for the isolation and purification of total lipids from animal tissues. Journal of Biology Chemistry, 226, 497-509.

Fontes, T.C. and Lopes, M.N.F. (1994). Congelamento de alimentos: Técnicas e normas, p. 68. Viçosa MG.

Fox, J.D., Wolfram, S.A., Kemp, J.D. and Langlois, B.E. (1980). Physical, chemical, sensory, and microbiological properties and shelf life of PSE and normal pork chops. Journal of Food Science, 45(4), 787-790

Garcia-Cruz, C.H., Hoffmann, F.L. and Bueno, S.M. (2000). Monitoramento microbiológico de lanches vendidos por ambulantes na parte central de São José do Rio Preto, SP. Higiene Alimentar, 11(75), 48-51.

Germano, P.M.L. and Germano, M.I.S. (2008). Higiene e vigilância sanitária de alimentos. 3rd ed., p. 986. Barueri: Manole 
Hamm, R. (1960). Biochemistry of meat hydratation: advances in food research. Cleveland, 10, 335-443.

Hughes, J.M., Oiseth, S.K., Purslow, P.P. and Warner, R.D. (2014). A structural approach to understanding the interactions between colour, water-holding capacity and tenderness. Meat Science, 98(3), 520532.

Kim, G.D., Jung, E.Y., Lim, H.J., Yang, H.S., Joo, S.T. and Jeong, J.Y. (2013). Influence of meat exudates on the quality characteristics of fresh and freezethawed pork. Meat Science, 95(2), 323-329.

Kołczak, T., Palka, K. and Łącki, J. (2005). Water retention, shear force and texture parameters of cattle psoas and semitendinosus muscles unfrozen and frozen during post-mortem ageing. Polish Journal of Food and Nutrition Sciences, 1, 17-26.

Laurenti, E., Bridi, A.M., Castro, V. and Shimokomaki, M. (2009). Impacto das anomalias suínas na indústria. Revista Nacional da Carne, 33(384), 2032.

Lindahl, G., Henckel, P., Karlsson, H.A. and Andersen, H.J. (2006). Significance of early postmortem temperature and $\mathrm{pH}$ decline on colour characteristics of pork loin from different crossbreeds. Meat Science, 72, 613-623.

Liu, W., Wang, Z. and Chen, Y. (2010). Effects of monochromatic light on developmental changes in satellite population of pectoral muscle in broilers during early posthatch. The Anatomy Record, 293(8), 1315-1324.

Lundgren, P.U., da Silva, J.A., Maciel, J.F. and Fernandes, T.M. (2009). Perfil da qualidade higiênico-sanitária da carne bovina comercializada em feiras livres e mercados públicos de João Pessoa/ PB-Brasil. Alimentos e Nutricao (Brazilian Journal of Food and Nutrition), 20(1), 113-120.

Monteiro Filho, A.F., Braga, M.E.D. and Cavalcanti Mata, M.E.R.M. (2002). Congelamento de carne suína a temperaturas criogênicas: Alterações de algumas características físico-químicas. Revista Brasileira de Produtos Agroindustriais, 4(1), 51-62.

Morgado, E.S., Sobrinho, A.G.S., Zeola, N.M.B.L., Silva, W.L., Tamele, O. and Souza, H.B.A. (2011). Influência do tipo de embalagem e tempo de armazenamento sobre os parâmetros qualitativos da carne ovina. Scientia plena, 7(10), 1-4.

Oliveira, S., Silva, J.A., Maciel, J.F. and Aquino, J.S. (2008). Avaliação das condições higiênico-sanitárias de carne bovina comercializada em supermercados de João Pessoa. Alimentos e Nutrição, 19, 61-66.
Osório, J.C.S., Osório, M.T.M., Jardim, P.O.C., Pimentel, M.A., Pouey, J.L.O. and Lüder, W.E. (1998). Métodos para avaliação de carne ovina "in vivo", na carcaça e na carne, p. 107. UFPEL.

Ramos, E.M. and Gomide, L.A.M. (Eds.) (2009). Avaliação da qualidade de carnes: fundamentos e metodologias. In Atributos de qualidade da carne, p. 39-50. MG: Editora UFV

Schlindwein, M.M. and Kassouf, A.L. (2006). Análise da influência de alguns fatores socioeconômicos e demográficos no consumo domiciliar de carnes no Brasil. Revista de Economia e Sociologia Rural, 44 (3), 549-572.

Silva Júnior, E.A. (1995). da Manual de controle higiênico-sanitário em alimentos, p. 394. São Paulo, SP: Livraria Varela

Silva, N., Junqueira, V.C.A. and Silveira, N.S.A. (2002). Manual de métodos de análise microbiológica de alimentos, p. 295. São Paulo: Varela

Straadt, I.K., Rasmussen, M., Andersen, H.J. and Bertram, H. C. (2007). Aging-induced changes in microstructure and water distribution in fresh and cooked pork in relation to water-holding capacity and cooking loss-A combined confocal laser scanning microscopy (CLSM) and low-field nuclear magnetic resonance relaxation study. Meat Science, 75(4), 687-695.

Verbeke, W., Pérez-Cueto, F.J., de Barcellos, M.D., Krystallis, A. and Grunert, K. G. (2010). European citizen and consumer attitudes and preferences regarding beef and pork. Meat Science, 84(2), 284292.

Xia, X., Kong, B., Liu, Q. and Liu, J. (2009). Physicochemical change and protein oxidation in porcine longissimus dorsi as influenced by different freeze-thaw cycles. Meat Science, 83(2), 239-245.

Zhu, M.J., Mendonca, A. and Ahn, D.U. (2004). Temperature abuse affects the quality of irradiated pork loins. Meat Science, 67(4), 643-649. 